\title{
Climate change and its impact on epigean and hypogean carabid beetles
}

\author{
PIETRO BRANDMAYR \\ ROBERTO PIZZOLOTTO \\ University of Calabria - Dept. DiBEST \\ (Biology, Ecology and Earth Sciences). Ponte Bucci \\ Cubo 4B, 87036 Rende (CS) - Italy \\ Correspondence: \\ Pietro Brandmayr \\ pietro.brandmayr@unical.it \\ piz@unical.it \\ List of non-standard abbreviations. \\ $\mathrm{AAD}=$ annual Activity Density \\ $\mathrm{CC}=$ Climate Change \\ CRUTEM = Central Research Unit for Temperature \\ IRC = Index of Rank Change \\ MSS = Milieu Souterrain Superficiel \\ RAD = Rank Abundance Distribution \\ $S A D=$ Species Abundance Distribution \\ SSH = Shallow Subterranean Habitat
}

Key words: space-for-time monitoring time-per-time, species decline, extinction species assemblages, phenology, global warming impact, long-term monitoring

Received February 12, 2016

Revised August 04, 2016.

Accepted August 10, 2016

\section{Abstract}

Background and purpose: The approaches to the impact of climate change on carabid beetles are highly differentiated. We review here most studies that tried to compare past situations with present time conditions that may concern ground beetle species, populations and phenology, area and upslope shifts. Both epigean and hypogean domains have taken in consideration and, whenever possible, all time scales addressed by the authors.

Materials and methods: The methods adopted vary in relation to the time scale. Geo-period studies cover the largest time lapse, and compare Plio-Pleistocene fossil species assemblages with present ones. Further approaches concern long-term observations based on museum materials and the response of carabids to climate or man-conditioned habitat changes. Primarily devoted to the understanding of climate change impacts on communities are the space-for-time and the time-per-time approach, that imply the comparison of year samples collected in the same site after some decades. Other long-term studies are devoted to the phenology changes. The impact on cave dwelling carabids has studied by recording the new taxa discoveries during the last two centuries.

Results: Geo-period studies reveal strong area expansions restrictions or local extinctions of presently living ground beetles. The old idea of a stability of taxonomic status of such beetles seems to give way to a more dynamic vision of speciation events during the Quaternary, as suggested by recent population genetics studies on Trechines and some Carabus species. Long term studies based on museum materials reveal population and area declines of large and brachypterous species of open lands, but the climate responses are difficult to disentangle from anthropogenous habitat and landscape modifications. The space-for-time approach focuses especially glacier forelands but seems promising also in forecasting species declines starting from climate gradients in forests. The time-for-time (time lapse) monitoring of ground beetle assemblages has adopted so far in Mediterranean mountains and Dolomites. It reveals that in the last three decades a strong uphill shift has observed especially in open land assemblages. In the Dolomites local extinctions and decline of species' diversity has recorded around or above the tree line. The long-term monitoring of carabids in defined habitats provides extremely rich databases that can be useful in explain the relationships between climate change, population decline or increase and species phenology. Hypogean obligate troglobitic carabids revealed to be extremely sensitive to global warming, as testified by the continuous appearance of new highly evolved taxa that concentrate in the periods of fastest temperature rise of the last century.

Conclusions: Epigean and hypogean carabid beetles are excellent and "multitask" indicators of climate change. Moreover, their response time to climate changes seems to be shorter than for plants. 


\section{INTRODUCTION}

This paper is a short review of studies carried out so 1 far on the impact of climate changes on carabid beetles. In Europe and in Northern America this topic has been endeavoured through long-term studies both at community as well as at species population level, and it seems important to make a first balance of the evidence so far acquired. The research papers we discuss here have selected focusing on the specific topic „climate change impacts" on carabid species, faunas, populations and species assemblages or communities. This means that all the works compare data related to past situations with recent or contemporary ones, or that they allow to understand a „before versus now” caused by climate changes, global warming, etc. Problems of faunal history, biogeography and biodiversity hotspots have sometimes encompassed in the treatise if necessary. Details on methods have introduced only if relevant for certain new approaches, like the time-per-time studies of communities, which need perhaps a further elaboration.

The approaches in carabid studies have conspicuously diversified, and first we review (1) that on epigean carabid beetles. Those have subdivided in (1a) geo-period climate changes, from the Plio-Pleistocenic age to present, most examining fossil records $(1,2,3,4,5,6)$ and in (1b) long term (last century or shorter) community or population dynamics related to climate and land use changes $(7,8$, 9). Here we report on the (1c) „space-for-time approach”, very useful in areas where the glacier retreat has been followed during the last centuries (10), but also in forests (11), and on (1d) the time for time approach $(42,43)$. A separate section (2) is devoted to the problem of changing phenologies, as pursued by the Drenthe Biological Station (from 1959, (12)) or by Pozsgai \& Littlewood (9). Finally, a third section (3) reviews the impacts of climate change on hypogean carabid beetles, a field in which the studies are more or less at the beginning.

Carabidologists are usually very concrete people that like to discuss robust data and are often focusing on single species problems. Nevertheless, if we look from „outside” at the debate on climate change impacts, it becomes clear that a large amount of papers published on this topic are dealing with forecasting and theoretical hypotheses on the future scenarios, species, communities, biomes (13). Moreover, most tropical regions strongly threatened by $\mathrm{CC}$ are severely under-represented in climate-change ecology studies and majority of scientific publications have conducted in the temperate forests of Europe and North America (14). The use of models is largely widespread in predicting or simulating not only species range shifts at large (e.g. continental) scale or at small scale (by introducing variables like ecological interactions), but also community and biome shifts based on different general circulation models (GCMs) and biodiversity models and grids (13). The complexity of such attempts of forecasting or simulations is excellently presented in a recent review by Lavergne et al. (15), who discuss the potential ways to integrate feedbacks between ecology and evolution in predicting how climate change will affect species distributions and species assemblages. The authors addressed some crucial topics: i) niche conservatism versus rapid adaptive evolution, ii) the effects of ecological interactions like competition, trophic relationships, iii) the „individualistic response of species assemblages to CC, iv) last, but not least, the effects of specie's evolutionary origin on communities and ecosystems. Concerning „future issues”, the authors emphasize:

a) the need of reliable biological indicators (e. g., species traits),

b) eco-evolutionary forecasting that involves dispersal as key factor for species evolution, geographic range and response to global change,

c) the need of more progress to determine the relative importance of neutral versus niche-based rules of ecosystem assembly to simulate future species assemblages,

d) the need for testing and parametrization of ecoevolutionary forecasts against experimental data collected in the field.

It seems that some of these „future issues” are cut out for carabidologists, and in fact we started as research group more than 10 years ago with a new community approach to global change impacts: the „time-for-time” (time lapse) method, that consists in careful re-sampling

\section{BOX 1 - CAMPAIGNS ON TERRESTRIAL INVERTEBRATE COMMUNITIES IN ITALY}

In the seventies and at the beginning of the eighties several assemblage descriptions have accumulated in the Dolomites (16), in the Nebrodi Mountains in Sicily (17), in the Pollino National Park (1977, unpublished) and in other regions of Italy. The most important surveys have performed in the frame of the »Progetti Finalizzati» of the Italian CNR (Zoocenosi terrestri, coordinator: Prof. Marcello La Greca). In the Dolomites the altitudinal range of the sampled sites covered all climax and some man-conditioned habitats from the valley bottoms to the alpine prairies above the treeline $(1000-2250$ $\mathrm{m}$ a. s. 1.). Beyond vegetation, the animal taxonomic groups involved are butterflies, carabids, hydroadephagan families, staphylinids, coprophagous scarabeids, cerambycids, chrysomelids, nitidulids, curculionids, centipedes, harvestmen and nematods (18). An even larger gamma of animal groups has been collected and published, on various journals, for the Nebrodi chain in Sicily. 
previously studied sites. The results we expose later for Italy have based on a wide background of research campaigns started around 1970 (see box 1).

In the following pages we try to give a synthetic picture of the present knowledge on carabids and climate change, briefly discussing the results of the different approaches on epigean carabids and on the changes in phenology. The last part of this paper is devoted to a complementary ecological domain, the hypogean carabid fauna and its responses to the global warming, a topic that could be of particular interest for people working in karstic countries like Croatia and the neighbouring states of southeastern Europe.

\section{1) The impact of climate change on epigean carabid beetles.}

\section{1a) Geo-period climate changes.}

Such changes have mainly studied by examining fossil or sub-fossil materials, as well documented by several papers, already cited in the introduction. The interpretation of results is, speaking in general for the Quaternary, as a time of stasis in speciation $(3,5)$ and of strong migration from North to South and vice versa during respectively cold and warm phases. Of particular interest is the synthesis given by Ashworth (3) on the fossil findings of arctic beetles along the southern border of the Laurentide ice sheet from Iowa to New York State. Here (Fig. 1) the arctic-alpine coleopteran species went extinct at about 17,400 calibrated years BP (based on a calibration of $\mathrm{C}^{14}$ radiocarbon ages, here corresponding to more or less $14,500 \mathrm{y} \mathrm{BP})$. In the same figure we combined the data about the replacement of open ground species by forest species at the end of last glaciation in southern Chile. The comparison of the two curves gives us an idea of the panglobal extension of the postglacial warming in all continents, and of the related species migration in the two hemispheres. Similar events have described for northern Europe and in particular for the British Isles, where e.g. Diacheila arctica probably disappeared around cal yr $11,500 \mathrm{BP}(10,000 \mathrm{yr} \mathrm{BP}$, at the end of the Younger Dryas Stade). In southern Europe data on late-glacial fossil findings are scarcer, but the fossil Arthropods from a fullglacial site near Verona (19) revealed among some wetland species such as Elaphrus uliginosus and Pterostichus diligens rests of an „arctic” species, Amara (Curtonotus) alpina. This carabid is now living circumpolar in the alpine zone and on the fellfields of Fennoscandia, of Northern America and along the northern Eurasian border.

North-South migrations and vice versa have been often substituted in the inlands of larger continents, like Siberia, by longitudinal area restrictions, as observed e.g. by Zinovyev (20) for some sub-boreal species like Poecilus ravus and Cymindis mannerheimi that 5,000 BP shifted their areas to the eastern Siberian relict steppes and the subalpine belt of Pamir and Altai mountains.

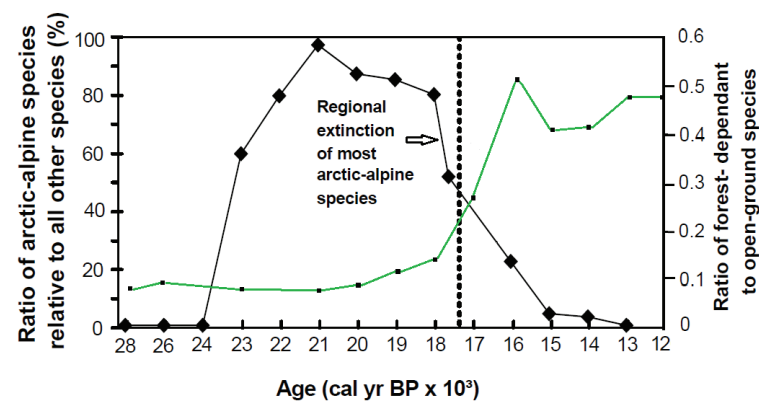

Figure 1. The appearance and disappearance of subarctic and arctic beetle species in fossil sites located along the southern margin of the Laurentide ice sheet (black line), and replacement of open ground species by forest species at the end of the last glaciation in southern Chile (green line). Redrawn from Figures 6 and 7 in Ashworth (3).

Notwithstanding the idea of insect speciation stasis has confirmed by Coope also in recent years (21), other authors $(3,22)$ seem less convinced of it. They think that the apparent lack of evolutionary changes may be due the fact that glacial faunas assemblages are composed by highly mobile hygrophilous taxa marked by good dispersal power, whereas less mobile endemic faunae of southern European mountains may show the genetic patterns of in situ adaptation. Recent phylogeography studies on Carabus irregularis in its central European and Alpine refugia show strong genetic divergence between the Carpathian clade and western populations at about $2 \mathrm{Myr} \mathrm{BP}$, and subsequent minor differentiation also in more recent times (23). Other species of the same subgenus Platycarabus (creutzeri and depressus) show even later divergence time, around 1,7 Myr BP, and subspecific divergence also in the last 500,000 years. Pleistocene genetic differentiation has found also for other Carabus species studied northward and southward of the famous and today rediscovered Holdhaus-line (24). In the genus Abax the appearance of some allopatric species (e. g.: continuus and parallelus) can be explained only in terms of ice age climate dynamics (25). A strong evidence for post-Pliocene species divergence has given also for west-Mediterranean troglobitic Trechines studied by Faille et al. (26), or alpine Trechine clades in the Plio-Pleistocene period (Faille et al., 27).

More authors finally point out that less mobile or forest dwelling species may be endangered by the incoming global warming (28), especially in the modern human conditioned fragmented landscape (5) and suggest for example assisted migration measures.

\section{1b) Long-term dynamics of carabid populations.}

Following the pioneer work of Carl Lindroth, several researchers and especially Piet den Boer and his co-workers in the Netherlands analysed large datasets partly derived by Museum collections and/or year samples obtained in nearly all habitat types of their country. These studies led 
to a fundamental paper about the „Foundation theory” (29), that subdivides carabid beetles in „high turnover” and "low turnover" species, in relation to their ability to found rapidly new populations based on their dispersal power. This paper laid the foundation for several new aspects of population theory in ground beetles (see also Lövei, (30)), including the metapopulation problem, and opened the long-term dynamics „reasoning” about the increase or decline of species in a country. Shortly later (31) a first mapping approach to the changes in occurrence of Carabids in the Netherlands was outlined, based on collection data starting from 1880. Poorly dispersing species generally showed decreasing time trends, probably as a consequence of habitat fragmentation, whereas the occurrences of well dispersing species appeared to be more stable, or increasing. Moreover, the effects of agricultural treatments for a test group of well dispersing species with a high tolerance for heavy fertilisation, resulted in distinctly increasing time trends, as expected. This approach was subsequently extended with similar results to Denmark, Belgium and Luxembourg (8).

Analogous studies were conducted in Belgium by Desender et al. (7) on a restricted data set of 26 species selected among the 380 known that time for Belgium. The authors concluded that in recent decades (more or less after 1950) „few common species have become relatively more common at the expense of a larger number of rare species which became even more rare". They attributed the decline of rare species like Carabus cancellatus, Carabus nitens, Cicindela germanica and others to the loss of natural and semi-natural habitats, especially grasslands, heathlands, dunes or extensively cultivated fields. The effects of climate change were probably overruled by habitat deterioration.

The data on distribution and numbers of carabids in Denmark, Belgium and The Netherlands were shortly later re-examined by Kotze and O'Hara (32) using ordinal regression to identify species traits as body size or wing status correlated with the decline of ground beetle species over the last century. They found that large-bodied carabids declined more than small-bodied ones, perhaps because of their lower reproduction power and frequent brachyptery. Decline was observed also in habitat specialist populations, as well as in monomorphic brachypterous or macropterous species, whereas pteridimorphic ones were less affected. Large carabids of open lands or grasslands habitats were disfavoured in comparison with large beetles of forests, coastal or riparian environments, but the reverse was found for body sizes $>8 \mathrm{~mm}$. The authors concluded that the climate effects in such western European are largely overwhelmed by anthropic pressure and „that even the species best 'equipped for survival' are at risk".

\section{1c) Space-for-time approach.}

This method is widely used in modelling and predicting biodiversity changes and infer past or future ecosys- tem trajectories from contemporary spatial patterns. Being continuous fossil chronosequences rarely available for carabid beetle communities, we can nevertheless accept the idea that a spatial sequence of habitats aligned on a climate or altitude gradient may be driven by the same climatic factor sets or subsets. Actually, the reliability of such comparisons has not tested adequately, but recent studies on fossil pollen relative abundances across Eastern North America (33) showed that „predictions based on space-for-time substitution were $-72 \%$ as accurate as time-for-time predictions". First space-for-time studies on ground beetles assemblages found an ideal context in the glacier forelands of the Alps $(34,35)$, because they offer the possibility to study primary successions of biota in previously desertified sites and to date with high precision since how many years a single small area has been colonized. In the last decades the community analysis has been refined by the search of correlations with vegetation and soil evolution and by the interpretation of species traits $(10,36)$. Some well-winged species (Ocydromus incognitum, Princidium bipunctatum, Nebria jockischii) are fast settlers of the bare stony soils $(10,37)$, whereas brachypterous followers, more of which forest dwellers, need more time and have to wait on a more structured habitat. Nevertheless, the picture get complicated by the ability of some wingless species to live on the „black glaciers”, i. e. the debris covered glacier tongues. This poorly investigated phenomenon has studied on the Miage Glacier (38), where a predator dominated community of spiders and a "cryophilic" Nebria species is living at the expense of aphids, flies and springtails. Black glaciers are probably of high importance for the survival of low temperature adapted species in the mountains (38), where they offer cool and stable subterranean spaces rich of organic substance and prey, a process that is known to favour the origin of alpine endemic invertebrates (39).

Studying the pioneer species assemblages of the barren terrains in front of glaciers, or that of the nearby vegetation-less talus slopes at high altitudes, scientists always wonder on the population density of predators in such habitats. These extreme environments lack of primary production and the most common hypothesis is that food is supplied by allochthonous material dropping, like organic particles and insects driven by upward winds. In a recent study based on modern PCR and stable isotope techniques a team of Austrian researchers (40) found that intraguild predation could play an important role in maintaining such communities. The glacier foreland of the Rotmoos in the Ötztal at the altitude of 2436-2418 $\mathrm{m}$ a. s. l. revealed that all carabid and spider species living there depend from a food web sustained by collembola, then by the decomposer pathway, but nearby all predators show also intraguild feeding in a different amount. The „top intraguild predator" seems to be Nebria jockischii, which feeds on the widest variety of prey, e. g. Pardosa spp., but is the less predated by other "guild members". 
Glacier front communities teach us that also at the "cold frontier" of life the biota behave as complex and well buffered systems that are constructed with taxa long time adapted to such extreme conditions. They develop anyway in the very energy rich conditions of temperate mountain chains and have eventually little in common with the energetic poverty and climate instability of arctic or Antarctic systems. In the more stable alpine elevations (and glacial refugia) an ensemble of endemic and most shortwinged ground beetle species (41) ensures with other arthropods long-lasting food chains in the nival belt.

Another interesting example of space-for-time study aiming to predict biodiversity gains and losses has been carried out in the Bavarian beech forests (11), by arranging the pitfall collecting plots in two series, one at country scale and a second restricted to the Bavarian Forest. The authors found that global change warming would favour five species and negatively affect six ones, with further five less influenced at all. Nevertheless, trying a balance between „winners and losers", the temperature increase would be detrimental for the "global responsibility" linked to biodiversity conservation in Germany, because three species, Pterostichus burmeisteri, P. unctulatus and Carabus auronitens will gradually become extinct in part of their range.

\section{1d) Time-for-time (time lapse) approach in epigean carabid beetles.}

Our first resampling attempt has been one in Southern Italy, in the Pollino National Park, at the border between Calabria and Basilicata regions. From the past (1977) three year samples were available: two beech forest sites, one belonging to the "cooler Fagetalia”: AsyneumatiFagetum, the other to the warmer beech belt: AquifolioFagetum, marked by the evergreen holly bushes. At the same altitude (1500-1600 m a. s. 1.) a meso-acidophilic pasture (Meo-Asphodeletum) belonging to the Corine habitat 35.72: „Southern Italian mat-grass swards”, heavily overgrazed by cows and with prevailing unpalatable herbs like Meum athamanticum (baldmoney) and As- phodelus albus. Twenty seven years later (2004) we resampled the same sites in the frame of a project aimed to construct a georeferenced biodiversity databank for evaluating the climate change impact in Southern Italian mountains (42). Despite the low year sample number, the strong difference between the response of forest species assemblages versus open land ones was immediately evident. After 27 years the beech forest maintained more or less the same species abundance distribution (SAD), whereas in the pasture the first three dominant species were replaced by „new entries” from much warmer habitats (Fig. 2 and 3). In the beech forest, dominated by tall trees of about 100 years age, the percentage similarity between the two dates was $72 \%$ for the Asyneumati-F. and $77 \%$ for the Aquifolio-F., the pasture on the contrary showed a total remixing with a PS value of $14 \%$ only. In both beech stands the „tail” of the SAD was infiltrated by thermophilous species (Steropus melas, Calathus montivagus, Carabus lefebvrei), but the abundance of all old dominating species raised because of the soil evolution processes and the cease of logging and wood hauling. In the pasture the three dominant species Amara sicula, $\mathrm{Ca}$ lathus melanocephalus and Nebria kratteri, a woodland carabid, were replaced by Calathus fuscipes, C. sirentensis and Steropus melas, forest species like Haptoderus apenninus and Trichotichnus nitens disappeared completely. Contemporary samplings in other open lands of the same mountain allowed us to "measure" a shift of the SAD of this habitat toward the Xerobrometum grasslands located at $1200-800 \mathrm{~m}$ a.s.l., with PS values ranging between 65 and 54 (average: 62,$2 ; \mathrm{N}=5$ ). In terms of uphill shift of carabid beetle assemblages, the changes observed are equivalent of a rise in altitude of about $300-500 \mathrm{~m}$. Figure 4 highlights the variation of the species assemblage of the Meo-Asphodeletum site (PMA1) after 27 years as it appears in an ordination obtained by correspondence analysis of all sampled habitats in the Pollino National Park (42).

This first experience in the Pollino N. P., despite it has been based on the comparison of only three sites (and on

\section{BOX 2 - METHODS FOR THE TIME-PER TIME APPROACH}

The time-per-time method we adopted for sites in Italy bases on the comparison of year samples collected at the same place and possibly using the same number of traps. The comparison of 1977-2009 samples has been carried out using the minimum percentage similarity PS (i.e., Renkonen index) of „before versus now” pair of sites. Moreover, on the Dolomites, the changes in species structure composition have been quantified by performing a new ad hoc index, in the attempt to measure the RAD (Rank Abundance Distribution) variation in „before versus now” pair of sites. This new index has been called IRC (Index of Rank Change) and is expressing the difference between two rank abundance distributions by calculating all the species rank shifts observed in the „before versus now” year samples. The formula sounds as follows:

$$
\text { IRC }=\Sigma\left|\operatorname{Rsp}_{\mathrm{iA}}-\mathrm{Rsp}_{\mathrm{iB}}\right| / \mathrm{A} \mathrm{U} \mathrm{B}
$$

where $A$ is the site sampled in the past, and $B$ is the same site sampled in the present, Rspi is the rank order of the ith species, with i ranging from 1 to $\mathrm{A} U \mathrm{~B}$ (i.e., the number of species from the union of A with B). 


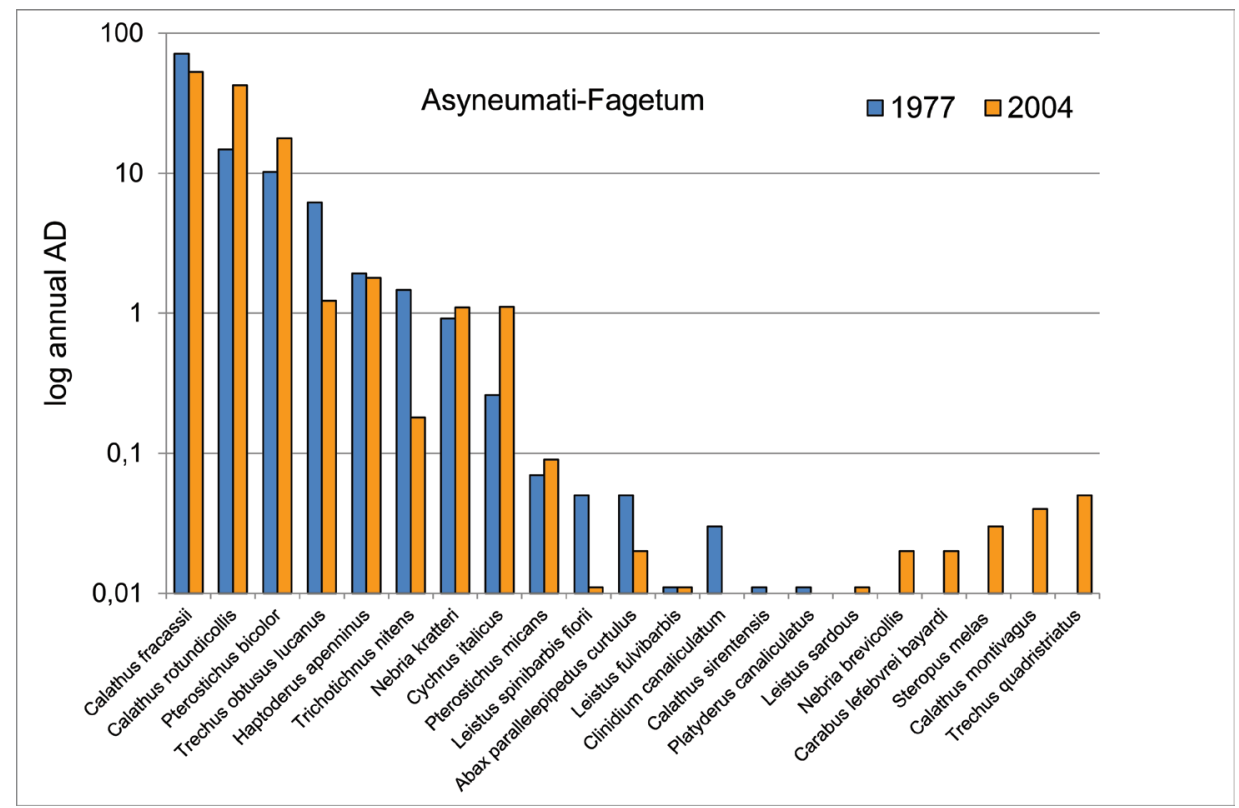

Figure 2. Before versus now species assemblages sampled in a "cool beech forest” located at 1580 altitude in the Pollino National Park. Ordinate: annual Activity Density calculated as individuals/trap in the standard period of 10 days (average value of the year sample).

the catch of about 21,000 beetles), suggested us that repeated year samples in the same habitat may be much more informative than single-species studies (see BOX 2). First of all, the climate change may depend from habitat type and structure, forests should be on average less sensitive than open lands. Second, insect communities seem to react faster to temperature changes than vegetation, even today the Meo-Asphodeletum site is classified as such, but the ground beetles assemblage living there is by far not more the same. Third, the time-for-time approach enables us to use all the elaboration methods typical of community studies and the interpretation possibilities offered by the „species traits”.

Starting in 2008, a second project has been entirely devoted to the climate change impacts in the Dolomites. These mountains located beneath the south eastern border

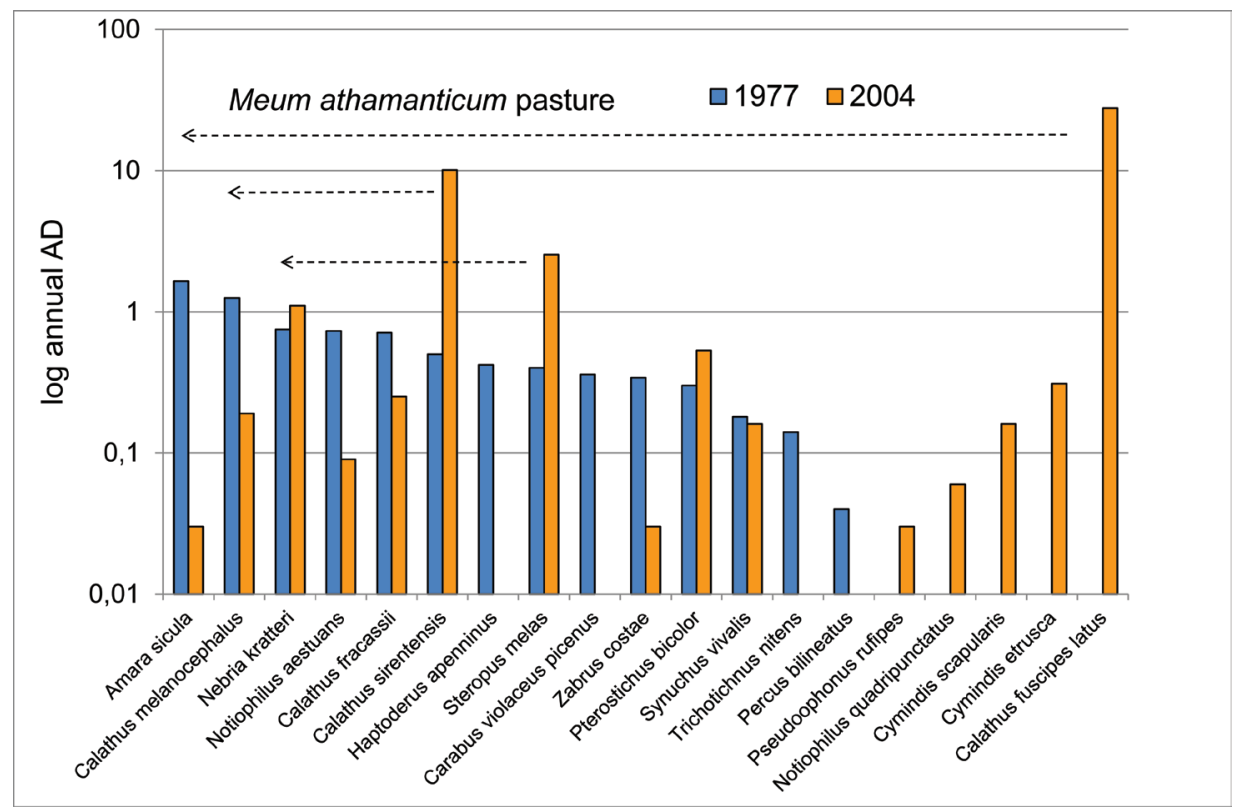

Figure 3. Before versus now species assemblages sampled in a mesic pasture located at 1512 altitude in the Pollino National Park. Ordinate as in fig. 2. 


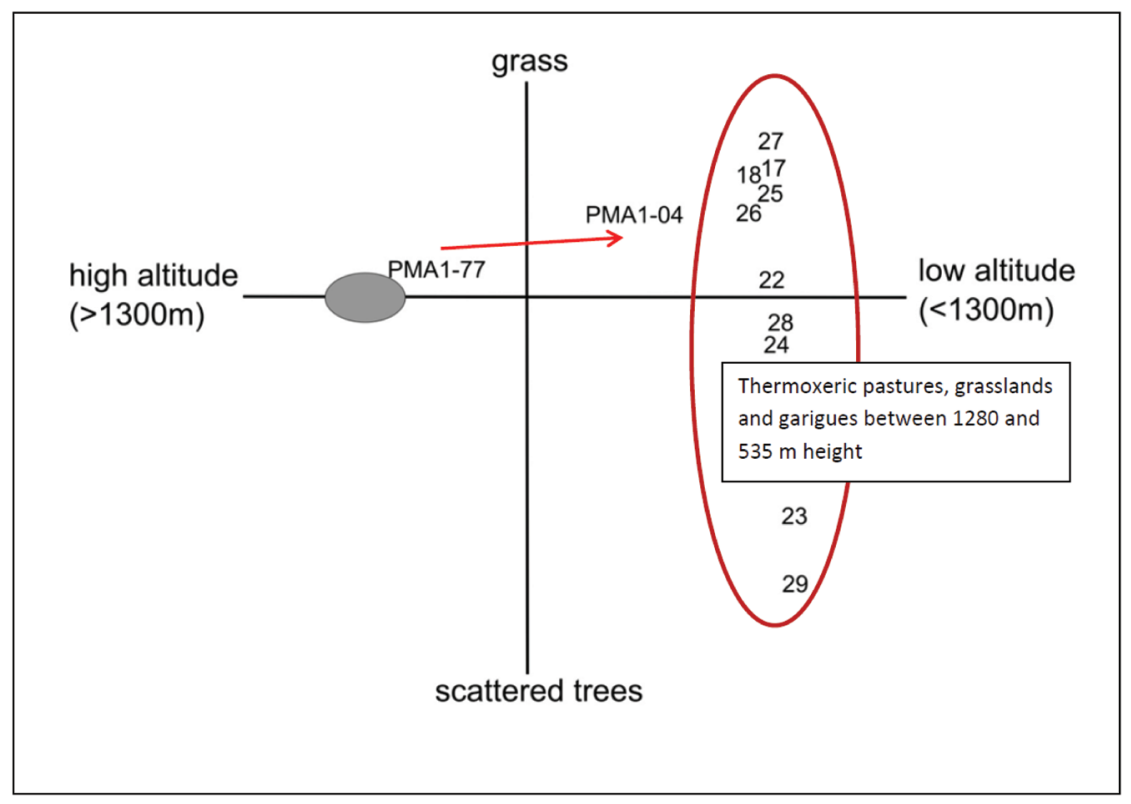

Figure 4. Ordination of Pollino sample sites after correspondence analysis, showing the critical position of the mountain pasture PMA1 in the years 1977 and 2004. The first axis (18\% of the total variance) is clearly linked to an altitudinal gradient, while the second axis (12\% variance) gives the ordination of the sample sites with thermoxeric microclimate conditions, and with vegetation structure characterized by scattered trees at the bottom of the axis, and by grasslands (Mediterranean garigue) at the upper end. Redrawn from Pizzolotto et al. (42).

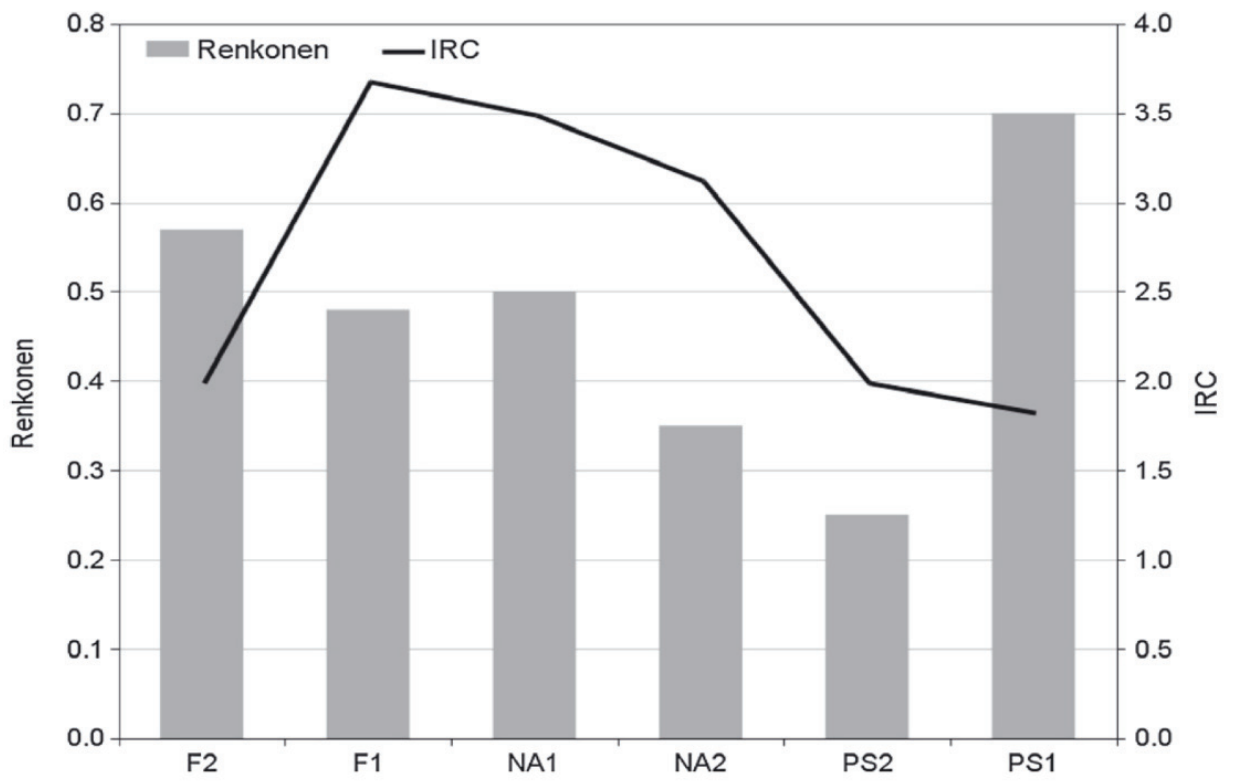

Figure 5. Renkonen minimum percentage similarity versus IRC (index of rank.abundance change) in the six „before and now” sampled sites. The stands are ordered by decreasing altitude from left to right. F2, F1 - Firmetum alpine grass mat. NA1, NA2 - Nardetum alpigenum. PS2, PS1 - Piceetum subalpinum. From Pizzolotto et al., (43).

of the Alpine chain suffer today by an extreme glacier retreat and annual precipitation lowering that threatens not only an outstanding habitat richness, but also a highly diverse endemic fauna and flora. Although about 30 year samples from 1979/80 were available on an altitude range of 1000-2250 m a.s.l., we concentrated our first resampling (43) on the habitats around the treeline of the Rolle Pass and on the western side of the Pale di S. Martino, a huge dolomitic massif that reaches $3194 \mathrm{~m}$ on the pinnacle of "Cimon della Pala”. The six sampled sites ranged from the subalpine spruce forest at $1650 \mathrm{~m}$ (Piceetum subalpinum, two sites) through the anthropo-zoog- 


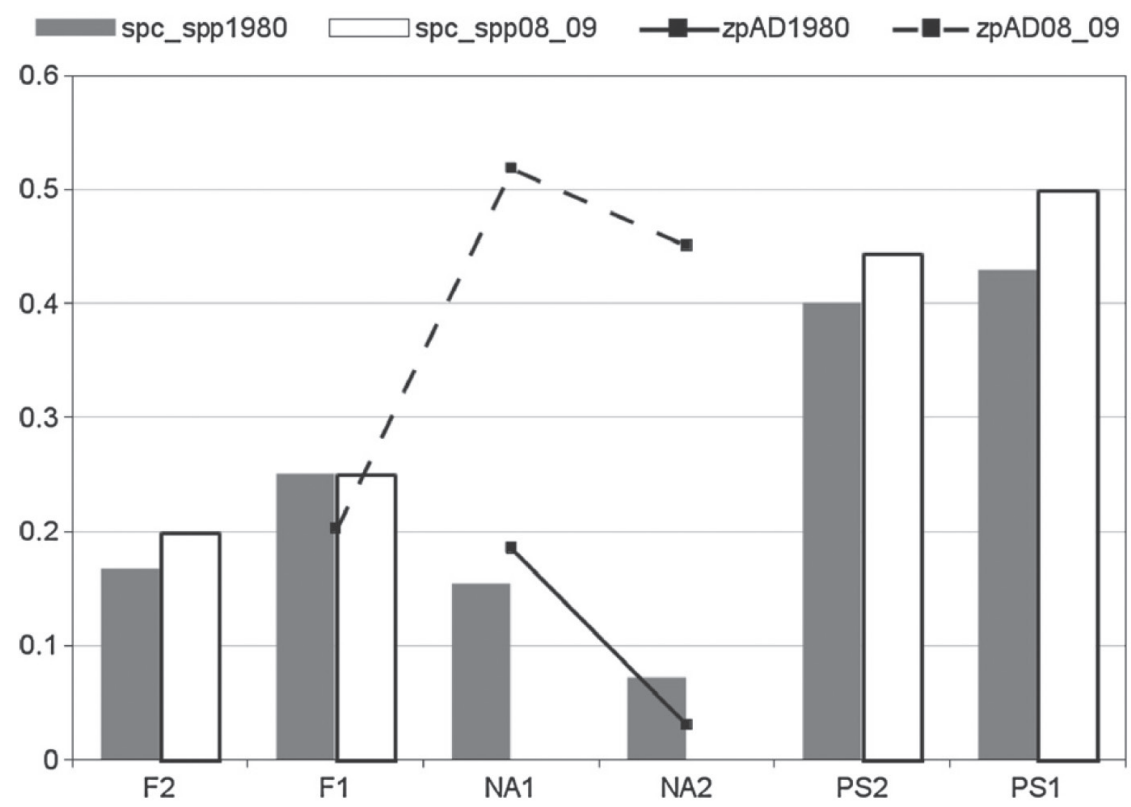

Figure 6. Incidence of specialized predators (spc_spp, \% of species) in 1980 versus 2009, and changes in the activity density percentage of opportunistic zoophytophagous individuals (zpAD) in the same time span. From Pizzolotto et al., (43).

enic mat grass pastures (Nardetum) until the alpine original grasslands on dolomite bedrock at $2250 \mathrm{~m}$ height (Carex firma calcareous grasslands).

The results showed also in 2008/09 an absence of variation in the between-groups similarity: the three groups, alpine grass mats, Nardetum pastures and spruce forests remained well distinct even after 30 years, while the intra-group similarity changed in grasslands and pastures, where the old samples were closer each other than the "now” ones. Moreover, in 2008/09 less species were sampled (27 versus 32), of the total of 36 nine species were found only 1980 and four only thirty years later. It seems that on the whole the climate change is leading to a turnover that shrunk the fauna sampled in 2008-2009. On the contrary, the annual activity density (aAD) raised from 29 specimens /trap in 1980 to about 59/trap in 2009, at least in part as a consequence of raised temperatures that accelerate the locomotory activity.

Going to analyze the „before versus now” assemblage structures, the PS index indicates the deepest changes in the habitats around the treeline (from F1 to PS2, fig. 5), where grazing pressure is high (NA2) or logging recent (PS2). The IRC index behaves in an opposite way, the highest values are found in grazed open lands, suggesting that the highest species turnover is found in such habitats.

Also species traits are of great help in interpretation of the changes observed. The incidence of specialized zoophagous predators (species) in the six habitats (Fig. 6) remains constant in forests and in the less or not disturbed alpine prairie, but this sensitive component disappears in the grazed pastures. On the contrary, the aAD of omnivorous (zoophytopagous) individuals shows a remarkable increase after thirty years, favoured by higher temperatures and soil dryness.

Trying to synthesize the core meaning of the changes observed, following points should be emphasized:

1) in the alpine prairies (sites F1 and F2) the most remarkable variation is the disappearance of Nebria germari and the strong abundance reduction in Trechus dolomitanus. The local extinction of the microtherm carabid $N$. germari is impressive, because this eastern alpine endemic beetle suffers now by increasing area restrictions and seems confined in habitats above 2400-2500 m a.s.l., at least in the Dolomites (unpublished data).

2) In the F1 site, an alpine grassland beneath the treeline, the number of species remained the same, but four microtherm or hygrophilic species disappeared (Patrobus septentrionis, Notiophilus biguttatus, $T$. dolomitanus, and $N$. germari), and were replaced by new four species (Cychrus caraboides, $T$. pallidulus, Amara praetermissa, and Calathus melanocephalus). The Rolle Pass represented for the boreomontane carabid P. septentrionis the southernmost locality in Europe!

3) In the Nardetum pasture NA2, the most disturbed by overgrazing, seven hygrophilic or microtherm species disappeared, among them Pterostichus rhaeticus, Nebria gyllenhali and Bembidion bipunctatum, 
testifying that the temperature rise is combined with an increasing dryness and lowered snowfall.

4) More generally, in open habitats above or around the treeline species' responses can distinguished in: local (population) extinction, uphill shifting, more or less stable populations, habitat reduction. In the forest belt more species showed a strong increase in population density (Pterostichus jurinei, Haptoderus unctulatus, Calathus micropterus) and an increase of thermophilic ground beetles, among them Carabus germari and $C$. auronitens. These changes could be related with the strong reduction of the Sphagnum covering of the soil, in turn mirroring the annual precipitation decrease.

\section{2) Changes in phenology and life cycles.}

The changes in phenology of Carabid beetles are by far not so well followed as observers do for other higher taxa (especially Vertebrates, but also butterflies or plants, see (44)), but we know that several species may change their reproduction rhythm from annual to biennial along latitudinal or altitudinal gradients $(22,45)$. What unfortunately has much less investigated are the temporal shifts of carabid phenology through the last decades, when the impact of global change becomes more evident. An exception is given by the work of various authors (12), started 1959 by Piet den Boer, chairman of the Foundation WBBS, Drenthe, Netherlands, with weekly catches in two heathlands: Kralo and Hullenzand (1963). The data so far elaborated can summarized as follows:

1) The average temperature has increased with $1^{\circ} \mathrm{C}$ in the last few decades, as well as the sunshine hours

2) Temperature, precipitation and sunshine are highly influencing the total amount of captured beetles and the start and end of activity season

3) After a significant increase of beetle catches during the early 90's, almost all species show a decline in recent years. Only four species show a positive response to the increase of temperature and sunshine.

4) Northern species seem to suffer from CC, protected species like the peat moor dweller Agonum ericeti are particularly affected by wet, warm winters.

5) Out of the 20 species analysed, only four started the activity season significantly earlier in the period after 1988, day active species such as Carabus arcensis, Poecilus lepidus and P. versicolor belong to this group.

6) High temperatures during the winter months cause a slow start of the active season, perhaps the coldperiod requirements of some species are not „fulfilled".
7) Higher temperatures and sunshine accelerate the development of adult beetles, leading to an anticipated end of the activity season.

A similar study is running in Scotland in the frame of the UK ECN (Environmental Change Network) activities (9), and shows that there could be a connection between phenology changes and species decline. Twentyfive most abundant species have monitored over an 18-year sampling period by pitfall traps and several phenological parameters analysed. Eight species declined in activity density over time, three increased and fourteen showed no change, but most changed their phenology. Anticipated onset of activity and earlier ending were the most pronounced changes, but also some advancing of activity peaks has observed. Declining species has found more in bog or moorland habitats compared to grassland, and the dropping of activity density has probably caused by a narrowing of the activity period due mainly to an earlier cessation. Timing of initiation of activity and changes in activity-densities are reciprocally related and this suggested that species more able to advance their phenology have less endangered by population decline.

Overall it seems that the climate change is in various modes affecting ground beetle phenology and by consequence the yearly reproduction rhythms, the life span, the mortality of larval and adult stages and that all this might depend on the habitat characteristics. A good reason for continuing and implement the monitoring programmes as suggested by more authors, at least because the life cycles of carabids are generally well endeavoured.

\section{3) Responses of hypogean carabid beetles.}

The adaptive radiation of carabid beetles is running along an incredible multiplicity of „evolutionary pathways", perhaps starting from tropical riversides, but anyway reaching a wide variety of endpoints, from tree canopies to polar climates or mountain tips (46). Along the tread that conducts from alluvial plains to rocky substrates and higher elevations, a possible „blind end” is represented by the subterranean evolution (47), that leads first to brownish microphthalmous forms and finally to cave dwelling anophthalmous more or less pale-yellow beetles, that acquired the so called "troglomorphic" habitus. The study of subterranean life is the target of Biospeology, a science born in Slovenia in the first half of the 19th century (47), and today cave beetles are known from all continents and especially from karstic areas, even if the Dinaric Karst of the Western Balkans remains a global biodiversity hotspot for obligate subterranean beetles (48). Subterranean beetles live especially in non-glaciated areas that showed in the last geo-periods a long-term stability of environmental conditions (49), especially of amounts of precipitation (57). 

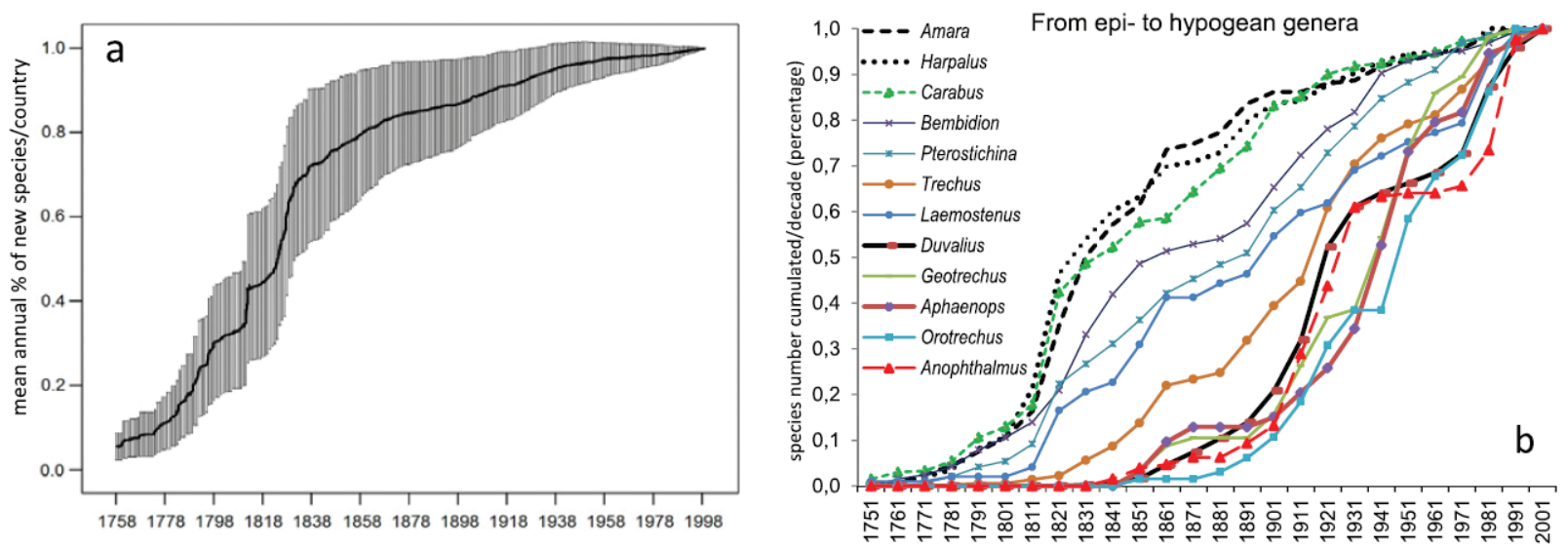

Figure 7. a-Species accumulation curve of the mean ( \pm 1 SD) annual percentage of newly recorded carabid beetles per country in the western palearctic region. Redrawn from (53). b-Species accumulation curves in European carabid genera ranked from true epigean forms to typical hypogean ones.

During my first scientific life in Trieste (author: PB) I had the opportunity to work and collect beetles with many biospeologists, among them Egon Pretner, who worked as biologist in Postojna, at the „Inštitut za Raziskovanje Krasa" of the Slovenian Academy of Sciences and Arts (SAZU). In the year 1978, during one of my visits, we examined together some intriguing beetles collected by Mr. Branko Jalžić, of the Croatian Museum of Natural History. One of those beetles was later described as Lovricia jalzici Pretner 1979, first representative of a new Bembidiine subtribe with somewhat „trechinoid” characters and very apart from all so far known cave carabids. In the same years many others new species or even genera of subterranean carabids were described, some of them curiously collected also in long time explored old caves. These events suggested me a possible connection with the striking changes shown by weather and seasons, especially the strong reduction of winter frosts on the Triestine Karst and in the surroundings of the city. Despite the evidence of climate change effects on vegetation, e.g. the expansion of evergreen laurel bushes outside the private gardens („laurophyllisation”) and other signals, I have forced patiently accumulate data on new descriptions, and some years later the compilation of the „Fauna Europaea” by Augusto Vigna Taglianti (50) was of great help. To investigate if global warming was in anyway involved in the sudden appearance of so many new taxa, and the possible relationship with the subterranean adaptation, we reconstructed an unprecedented set of species/time accumulation curves of the largest carabid genera in Europe, selected by their degree of 'underground' adaptation, from true epigean predators to eyeless highly specialized hypogean beetles. With the help of Giorgio Colombetta, a triestine carabidologist, we examined the species/time curves and the amount of descriptions/decade for the genera: Amara, Harpalus, Carabus, Bembidion, all Pterosti- china of Europe, Trechus, Laemostenus, Duvalius, Geotrechus, Aphaenops, Orotrechus, Anophthalmus, for total 2817 taxa (51). We found that truly epigean species showed a normal sigmoid curve, demonstrating a saturation of discoveries in the past century, whereas the more a genus or higher taxon was living underground, the more the accumulation curve showed periods of stasis alternating with other of fast increase of descriptions. In other words, the data showed that in recent periods an unexpectedly large number of new cave species were found „upwelling” from well established European hotspots. The first peak of new species, especially in the most evolved underground taxa, occurred in the 1920-30s and a second burst after the 70 s, thus exactly in correspondence with the two global warming bursts described for the northern hemisphere by temperature anomalies based on the 1961-1990 means of CRUTEM4 (52). In Figure 7 the sigmoid curve of species discovery for western palearctic carabids (53) is compared with the accumulation curves of epigean versus hypogean taxa of Europe. We maintained our study rigorously inside the European boundaries and with exclusion of the Caucasus mountain chain, because in other continents Biospeology is a much younger science.

To explain such curves two hypotheses were examined:

1) Global warming hypothesis. The subterranean ground beetles are so much sensitive to climate conditions, among others to low winter temperatures, that it is possible that 20th century global warming might have caused these populations to expand their hypogean habitat (or 'inhabitable volume') towards the earth's surface, leading to an increase of findings of new genera/species. Two important basic assumptions are: (a) because of sensitivity to winter frosts, habitat and range extent of hypogean carabid beetles tend to expand if the zone exposed to deep daily/ 

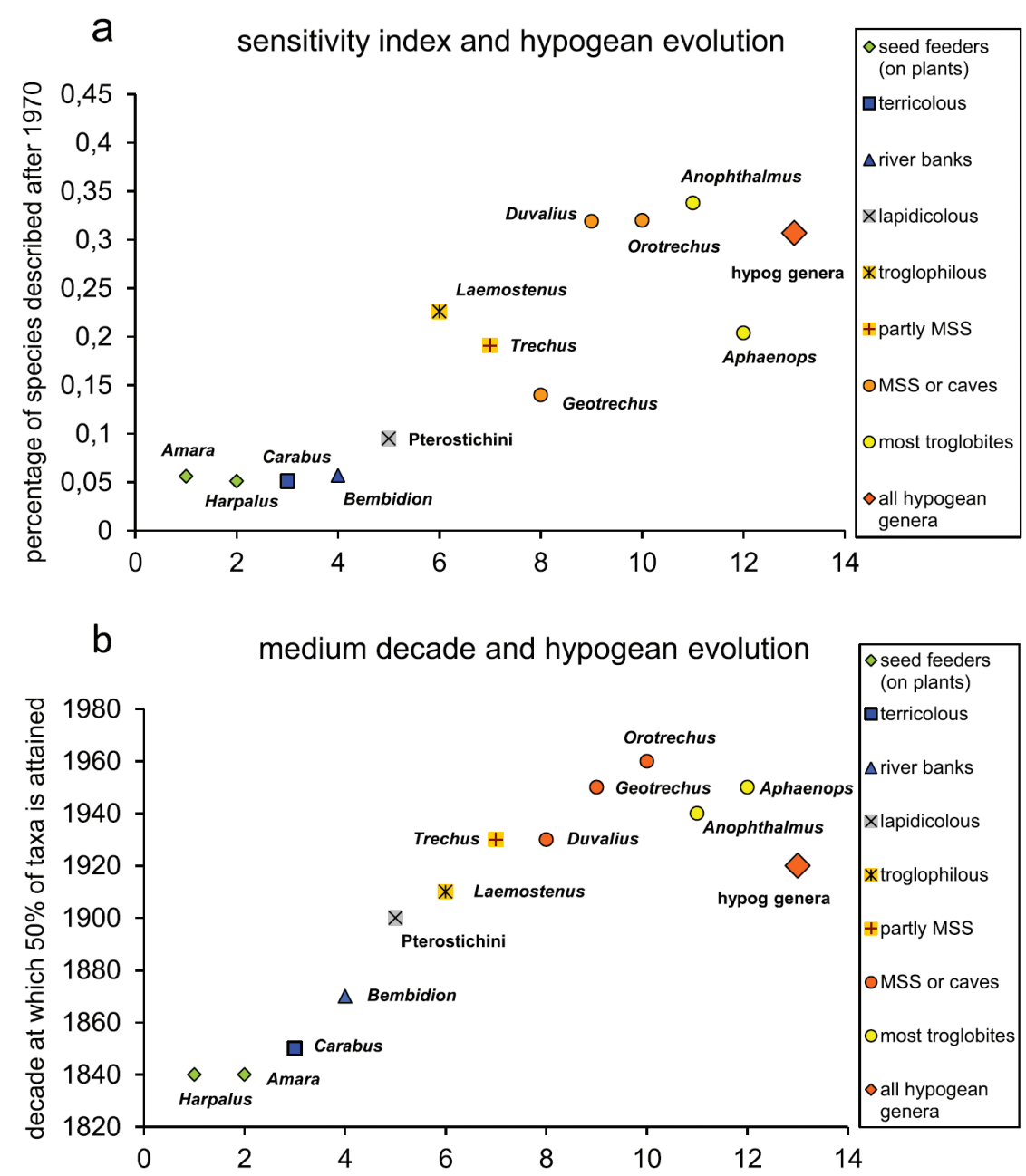

Figure 8. Hypogean evolution degree of large carabid genera or tribes versus sensitivity to global warming and delay in discovery (medium decade). $a$-Sensitivity expressed as percentage of species discovered after 1970. b-Decades in which each taxon (or taxa group) recorded $50 \%$ of the species actually known. The position of 'all hypogean genera' is arbitrary. From Brandmayr et al., (51).

monthly temperatures retreats towards the surface; (b) habitat shifts should have occurred especially after 1970, when the anthropogenic temperature increase was particularly marked.

2) Sampling intensity hypothesis. It may be that the number of biospeologists involved in collecting carabid beetles in subterranean environments may have increased in the last decades in such a way that previously neglected caves and taxa were finally discovered. This could be the consequence of new cave exploring techniques like the long-time trapping in the MSS (milieu souterrain superficiel) or in other kinds of SSH (shallow subterranean habitats, (54)). We addressed this second hypothesis by counting the authors and co-authors of all the descriptions recorded in the crucial taxa of highly evolved cavernicolous carabids, and comparing the species/decade statistics with the corresponding author numbers.
In fact, we found a much stronger correlation between the CRUTEM4 temperature curve and the species/subspecies curve of newly discovered taxa in Europe, with a correlation coefficient in the range of 0.84-0.92 for genera such as Aphaenops, Duvalius and Anophthalmus. Conversely, the author numbers were less related to the species curves, with correlation values around $0.60(0.56-0.65)$, and even 0.15 (for Anophthalmus). This clearly suggested that changes in sampling intensities alone could not explain so strong amounts of new findings, and that the contribution from rising temperatures was the main thriving factor.

Further parameters we examined were a mathematical expression of taxa sensitivity to the global warming, calculated as the percentage of species/subspecies discovered after 1970, and the „medium decade”, i.e. the decade that coincided with the $50 \%$ of taxa described within each genus. Plotted versus the degree of subterranean evolution of all taxa analyzed, both indexes raised with the degree 


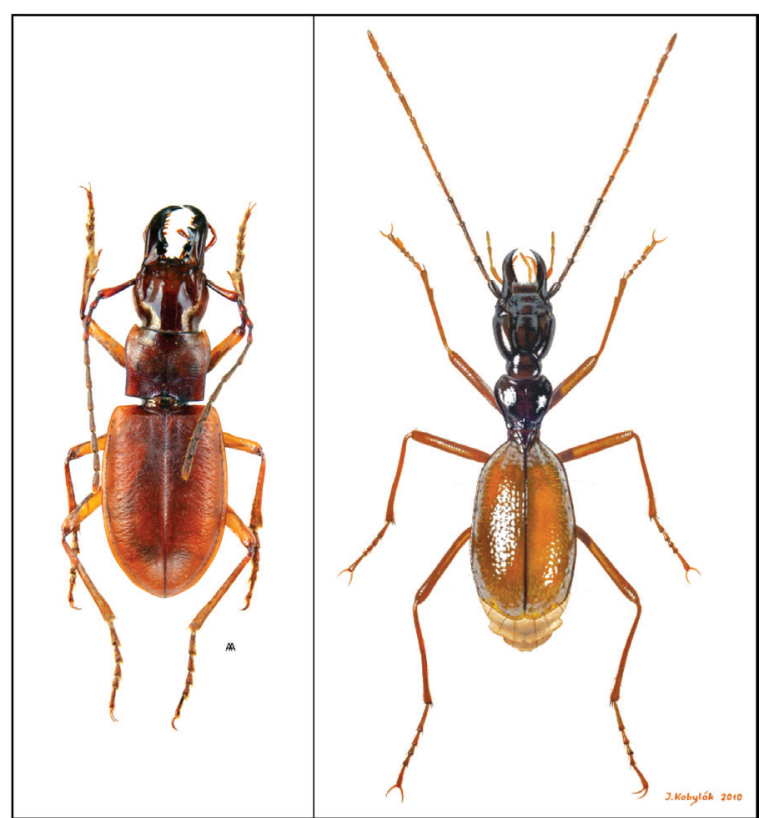

Figure 9. Left: Dalyat mirabilis Mateu. Copyright (C) Alexander Anichtchenko. From: Anichtchenko A. et al., (editors): Carabidae of the World. http://www.carabidae.org. Right: Velebitaphaenops giganteus Casale and Jalžic. Oil painting of Jan Kobilák in (55). Body length of Dalyat: 10-13 mm (56). Body length of Velebitaphaenops: $12,3 \mathrm{~mm}$.

of troglomorphy of each carabid group (Fig. 8) and were at their maximum in obligate cave dwellers.

If we look at the decadal sequence of newly described hypogean genera, the picture is even more impressive: more than $30 \%$ of obligate underground living carabid genera have been discovered after 1970 ! In the last decades Europe appears as a Pandora's box of carabid (sub)tribes previously unknown from the hypogean environment (Promecognathini: Dalyat mirabilis Mateu 2002; Lovriciina: genus Lovricia Pretner 1979, Neolovricia Lakota et al. 2009, Paralovricia Giachino et al. 2011) or shared with other continents (Platynini: Galiciotyphlotes weberi Assmann 1999; Zuphiini: Ildobates neboti Español 1966). The role of temperature rising in this process is supported also by the fact that new discoveries of European cave species are far from saturation, but show peaks in correspondence of periods of maximum warming, in particular in areas that have been explored since many years. Even in the best explored countries of Europe, as in Northeastern Italy or Slovenia, where the Science of Biospeology started and for apparently 'well known' genera such as Orotrechus and Anophthalmus, an increase of more than 30\% of taxa was recorded after 1970 (Fig. 8). Moreover, many of these new findings, especially from the Southern Alpine range and in the Dinaric chains, concern highly evolved troglobiont or aphaenopsian forms, normally living deep inside and in the more protected portions of the underground compartment. Among such impressive findings we should remember at least $\mathrm{Ve}$ lebitaphaenops giganteus Casale \& Jalžić 2012 (55), perhaps the largest „aphaenopsian” ground beetle never found in the world (Fig 9). The discovery of this last genus, found at $400 \mathrm{~m}$ depth is probably the product of new exploration techniques used by speleologists. We should anyway stress that the best proof that speaks for a direct response of troglobitic beetles to global warming has proved by the sudden appearance of new taxa in long time explored caves, as documented by the discovery of Anophthalmus spectabilis stygius Drioli 1982 in a cave of western Slovenia and for several Orotrechus, Duvalius and further carabid taxa. In otther cases we observe a range expansion of species known so far from few caves only. Speomolops sardous for example, a blind Molopine, was recorded in old times only for the "Grotta del Bue marino" in Eastern Sardinia and from other four caves around Dorgali, but in the last ten years it has been recorded for further eight caves lying more southern (Achille Casale, pers. comm.). Those "new appearances” happen most independently from the hotspot areas and the sampling intensity evaluations proposed in different manners (and very convincingly) by more authors especially for the northwestern Balkans $(57,58)$. Many ,aphenopsian” Orotrechus species have found in an exhaustively explored area of the southeastern Alps, and Lovriciina taxa have discovered both in intensively and non-intensively explored geographic sectors.

\section{CONCLUSIONS}

The steadily growing amount of knowledge concerning the climate changes in late Pliocene and Quaternary reveals an extremely changing framework of species' distributions, with fossil documented range shifts that reach or easily surpass distances of 1000-2000 km and altitude intervals of corresponding amplitude. This highly dynamic picture relates to a temperature lowering of $8-10^{\circ} \mathrm{C}$, as mostly assumed for the late glacial conditions of Eurasia or Northern America, and corroborated, at least in a first moment, Coope's idea of a marked evolutionary stability of the species involved. Recent population genetics research on short winged or apterous forms of carabids living in the alpine belt of North America (1), or bound to the more stable habitats of central and southern European mountains $(23,26,27)$, demonstrates that a part of actual taxa are the result of late Pliocene or Quaternary splittings. This idea was in fact normally accepted by botanists and zoologists working on the Alps and in the Mediterranean countries.

The studies on long term dynamics of carabid beetles, based mainly on Museum collections, concentrated in the Netherlands, Belgium and Denmark, and gave us for the first time an idea of the amount of local extinctions of the populations in the past century as a consequence of landscape and habitat changes. Especially large-bodied species of heathlands, pastures and grasslands are progressively 
disappearing from the maps, as well as monomorphic winged or brachypterous species, whereas dimorphic ones seem less affected by such deep transformations (32). Consequently, continuous monitoring of heathlands, as reported for example for the Kraloer Heath near Drenthe (12) can be effective only if the main habitat features are maintained rejuvenating the ecological succession by periodical soil removing every $10-15$ years. For such experimental areas a general species decline has been observed, only four ones show an increase of population density, but no species extinctions have been reported until today. The long-term dynamics approach seems to be very effective in assessing a faunal biodiversity balance at country scale, but less useful in evaluating climate change impacts on species, because of the difficulty to disentangle man management and habitat restoration/destruction trade-offs from the effects of temperature and other physical factors.

At the light of those last considerations, the Drenthe project and similar investigations (9) assume a crucial importance, because in the course of the years it could become a "sounding board" in testing the plasticity of carabid life cycles against global warming.

The space-for-time approach in predicting the climate change impact on carabid species and their assemblages is after all less used as one expects, despite of its predictive potential (33). This depends probably on the manifold variables which are involved in determinate the species abundance distributions in complex habitats, like forest areas or across wide altitude gradients. Primary successions on glacier foreland barren soils are surely more „inviting" topics because in such context the evolution of vegetation can be followed in parallel with the development of an animal community and the glacier watch services can provide for exact dating the steps, moreover, human disturbance is totally absent. Carabid beetles play a fundamental role in colonizing the extremely cold habitats above the treeline and are able to settle on „black glaciers" (38). They constitute in competition with spiders the main predatory component of such communities and live here primarily at the expense of the decomposition food chain, but intraguild predation constitutes another important food source (40).

Even if less adopted, space-for-time approach has been demonstrated to be useful in predicting climate change impacts on forest carabids and their conservation (11).

The time-lapse approach for epigean carabid beetle communities we adopted in our studies has much in common with the previously discussed Drenthe- or Scotland projects $(9,12)$, but it focuses more on species assemblages instead of phenology and is carried out in highly sensitive habitats that remain open to all possible man exploitation, if any, for some decades before the year sample is repeated. The total absence of conservation management and year by year trapping leaves the carabid populations totally undisturbed and free to react to all possible physical and biotic changes. As in the long term dynam- ics approach, one of the interpretations problems is given by several parameter changes: forest or herb canopy, soil organic content, habitat structure, leaf litter depth, which might be in conflict or collinear with climate change. The comparison of „before versus now” SADs in forests of Southern Italy mountains showed that in such high treebiomass habitats the specie's rank sequence is more or less maintained after about three decades, whereas in the adjacent pastures new settlers from warmer habitats have been able to substitute the old dominant beetles in a sort of ecological reversal. In the forests the change is weakly signalled by the arrival of a "tail” of thermophilic or eurytopic species, but the overall increase of annual activity density witness also for soil development and reflects probably also higher summer temperatures. In the pasture a remarkable ground beetle species turnover is not accompanied by a change in vegetation structure and composition, and this means that insects react much earlier to climate change than plants. To summarize, on the Apennine mountains of southern Italy the pasturelands show early warning signals of summer drought that speak for an uphill shift of insect communities of at least $300 \mathrm{~m}$. There is a strong chance that such pastures will become less suitable for cows and palatable only for sheep and goat. Parallel studies on Erebia populations in the same mountain massif show concordant results (59).

The study on the Dolomites represents a step forward in the time-lapse approach, in this highly sensitive area an entire landscape has been sampled at the beginning of the ' 80 s, and the first results from the habitats around the treeline reveal an even more impressive response from carabid assemblages. Here we observed local extinctions of once well abundant microtherm species (Nebria germari), the disappearance of many other cold preferring or hygrophilic grassland dwellers, a rise in thermophilic species both in forests as in pasturelands, where phytophagous species like Amara substitute zoophagous specialists. Considering all the six habitats so far analysed, species diversity is dropping, while population density of some forest or alpine grassland specialists is rising, in many cases with uphill shifting populations. Finally, man managed pasturelands (nardetum) or forest borders show the lowest „before versus now” percentage similarity, the forest core and the undisturbed pioneer cushions share maximal similarities and the lowest amount of species rank substitutions. The overall balance in terms of biodiversity looks negative: $N$. germari is a south-eastern alpine endemic, the relict Patrobus septentrionis populations of the Rolle Pass lived here at their southernmost area boundary.

Looking finally at the responses of subterranean carabids, it seems that the subterranean domain was very far from "sleeping” during the past century. Unfortunately, very little is known on the cave temperatures and their possible variation in consequence of climate change, except for a recent paper of Domínguez-Villar et al. (60), who studied for five years a gallery of the Postojna Cave 
complex in Slovenia, located at $37 \mathrm{~m}$ depth from the topographic surface and with limited air advection. They found that the bedrock is recording the local expression of global warming with a delay of 20-25 years, this time lapse being depending on the distance of the cave from the surface. Of course, the responses that we observed for most subterranean taxa were rather fast in comparison, and this is easily explained by the complexity of the cave systems, that consists also of an interconnected net of vertical shafts, galleries and cracks open to the winter frosts. If such frozen air masses persist over the warm season, the troglobite populations remain in their subterranean net of crevices (the „reseau freatique” of Jeannel), but if the winters become milder and minimum temperatures rise, cave beetles can expand their „inhabitable volume” and settle in habitats closer to the topographic surface or "reconquer" large caverns. A large part of such habitats, all more or less belonging to the SSH, have been dealt with by Culver and Pipan (54), and a graphic model of a subterranean cave system with its underground populations has been described in (51), figure S2 in suppl. data.

The extreme sensitivity demonstrated by subterranean carabid populations to the global change needs more attention from scientists, cave animals are good not only as „early warning” of the conditions of underground systems, but also as ecological indicators of the health of the subterranean water systems, and represent as „living fossils" an outstanding heritage of the history of life in past geo-periods.

At least two more general points should be remembered at the end of this paper. First, many of the approaches dealt with speak for a differing speed between insects and plants in reacting to climate change. Carabid assemblages seem to change faster than plant communities. This difference probably is markedly larger in man managed open lands, smaller in forests, but this remains at the moment a working hypothesis. Second, the evaluation of climate change impacts needs, at least for a biodiversity assessment, a study at landscape scale, a gap that should be (hopefully) filled in the next years.

Acknowledgements: The authors are highly indebted with an anonymous referee who substantially improved the quality of the manuscript by suggesting a better organization of the topics. Hans Turin (Renkum, The Netherlands) helped us with useful hints about long-term monitoring research.

\section{REFERENCES}

1. ASHWORTH A C 1996 The response of arctic Carabidae (Coleoptera) to climate change based on the fossil record of the Quaternary Period. Ann Zool Fennici 33:125-131

2. ASHWORTH A C 1997 The response of beetles to Quaternary climate changes. NATO ASI Series 47 Past and Future Rapid Environmental Changes: The Spatial and Evolutionary Responses of Terrestrial Biota. Brian Huntley et al. (eds), pp 119-127 http://dx.doi.org/10.1007/978-3-642-60599-4_9
3. ASHWORTH A C 2001 Chapter 8: Perspectives on Quaternary Beetles and Climatic Change. In L C Gerhard, Harrison W E and Hanson B M (eds) Geological Perspectives of Global Climate Change. American Association of Petroleum Geologists Studies 47:153-168. Tulsa, Oklahoma.

4. COOPE G R 1977 Fossil coleopteran assemblages as sensitive indicators of climatic changes during the Devensian (last) cold stage. Phil Trans Roy Soc Lond B280:313-340 http://dx.doi.org/10.1098/rstb.1977.0112

5. COOPE G R 1978 Constancy of insect species versus inconstancy of Quaternary environments. In Mound L A \& Waloff N (eds) Diversity of Insect Faunas. Entomol Soc. Lond Sym 9:176-187

6. COOPE G R, LEMDAHL G 1995 Regional differences in the Lateglacial climate of northern Europe based on coleopteran analysis. J Quat Sci 10:391-395

7. DESENDER K, DUFRÊNE M., MAELFAIT J P 1994 Long term dynamics of carabid beetles in Belgium: a preliminary analysis on the influence changing climate and land use by means of a database covering more than a century. Desender et al (eds) Carabid Beetles: Ecology and Evolution. Kluwer Academic Publishers, p 247-252

8. DESENDER K, TURIN H 1989 Loss of habitats and changes in the composition of the ground- and tiger beetle fauna in four WestEuropean countries since 1950 (Coleoptera: Carabidae, Cicindelidae). Biol Conserv 48(4): 277-294. http://dx.doi.org/10.1016/0006-3207(89)90103-1

9. POZSGAI G, LITTLEWOOD N A 2014 Ground beetle (Coleoptera: Carabidae) population declines and phenological changes: is there a connection? Ecol Indic 41:15-24 http://dx.doi.org/10.1016/j.ecolind.2014.01.029

10. GOBBI M, ROSSARO B, VATER A, DE BERNARDI F, PELFINI M, BRANDMAYR P 2007 Environmental features influencing Carabid beetle (Coleoptera) assemblages along a recently deglaciated area in the Alpine region. Ecol Entomol 32:282-289. http://dx.doi.org/10.1111/j.1365-2311.2007.00912.x

11. MÜLLER-KROEHLING S, JANTSCH M C, FISCHER H S, FISCHER A 2014 Modelling the effects of global warming on the ground beetle (Coleoptera: Carabidae) fauna of beech forests in Bavaria, Germany. Eur J Entomol 111 (1): 35-49.

12. VARIOUS AUTHORS - The Effects of Climate Change on the Phenology of Carabid Beetles in Drenthe. Abstract and full report: http://www.biological-station.com/Abstract.xml

13. HANSEN A J, NEILSON R P, DALE V H, FLATHER C. H, IVERSON L R, CURRIE D J, SHAFER S, COOK R, BARTLEIN P J 2001 Global Change in Forests: Responses of Species, Communities, and Biomes. Bioscience 51(9):765-779

14. FELTON A, FISCHER J, LINDENMAYER DB, MONTAGUEDRAKE R, LOWE AR, SAUNDERS D, FELTON AM, STEFFEN W, MUNRO NT, YOUNGENTOB K, GILLEN J, GIBBONS P, BRUZGUL JE, FAZEY I, BOND SJ, CAROLE P. ELLIOTT CP, MACDONALD BCT, L. PORFIRIO LL, WESTGATE M, WORTHY M 2009 Climate change, conservation and management: an assessment of the peer-reviewed scientific journal literature. Biodivers Conserv 18:2243-2253 http://dx.doi.org/10.1007/s10531-009-9652-0

15. LAVERGNE S, MOUQUET N, THUILLER W, RONCE O 2010 Biodiversity and Climate Change: Integrating Evolutionary and Ecological Responses of Species and Communities. Annu Rev Ecol Evol Syst 41:321-350 http://dx.doi.org/10.1146/annurev-ecolsys-102209-144628

16. BRANDMAYR P, ZETTO BRANDMAYR T (con la collab. di R. Pizzolotto), 1988 Comunità a Coleotteri Carabidi delle Dolomiti Sudorientali e delle Prealpi Carniche. Studi trent Sci nat 64, Acta biol suppl.:125-250

17. PIZZOLOTTO R, BRANDMAYR P 1990 Ground beetle coenoses in the landscape of the Nebrodi Mountains, Sicily (Cole- 
optera, Carabidae). In: Bruno Massa (ed.): „Omaggio a G. E. Hutchinson“. Naturalista sicil S. 414 (suppl.):51-64

18. BRANDMAYR P (ed) 1988 Zoocenosi e paesaggio I. Le Dolomiti - Val di Fiemme e Pale di S. Martino. Studi trent Sci nat 64, Acta biol suppl p 482

19. FODDAI D, MINELLI A 1994 Fossil Arthropods from a FullGlacial Site in Northeastern Italy. Quaternary Res 41:336-342 http://dx.doi.org/10.1006/qres.1994.1038

20. ZINOVYEV E 2008 A history of ground-beetle faunas of West Siberia and the Urals during the late Pleistocene to Holocene. In Penev et al. (eds) Back to the Roots and Back to the Future. Proc XIII Eur Carabidol Meet Blagoevgrad Aug 20-24 p 241-254

21. COOPE G R 2004 Several million years of stability among insect species because of, or in spite of, Ice Age climatic instability? Phil Trans R Soc London B 359:209-214 http://dx.doi.org/10.1098/rstb.2003.1393

22. THIELE H U 1977 Carabid Beetles in their environments. Springer, Berlin 369 pp. http://dx.doi.org/10.1007/978-3-642-81154-8

23. HOMBURG K, DREES C, GOSSNER M M, RAKOSY L, VREZEC A, ASSMANN T 2013 Multiple Glacial Refugia of the Low-Dispersal Ground Beetle Carabus irregularis: Molecular Data Support Predictions of Species Distribution Models. Plos One 8(4): e61185 http://dx.doi.org/10.1371/journal.pone.0061185

24. DREES C, MATERN A, Von OHEIMB G, REIMANN T, ASSMANN T 2010 Multiple Glacial Refuges of Unwinged Ground Beetles in Europe: Molecular Data Support Classical Phylogeographic Models. In: Relict Species, Phylogeography and Conservation Biology (ed by. Habel J.C. \& AssmannT.) pp. 199-215, Springer-Verlag Berlin Heidelberg.

http://dx.doi.org/10.1007/978-3-540-92160-8_11

25. BRANDMAYR P 1977 Ricerche etologiche e morfofunzionali sulle cure parentali in Carabidi Pterostichini (Coleoptera, Carabidae: Pterostichini). Redia 60:275 316

26. FAILLE A, CASALE A, RIBEIRA I 2010 Phylogenetic relationships of Western Mediterranean subterranean Trechini groundbeetles (Coleoptera: Carabidae). Zool. Scripta 40(3):282-295 http://dx.doi.org/10.1111/j.1463-6409.2010.00467.x

27. FAILLE A, CASALE A, BALKE M, RIBERA I 2013 A molecular phylogeny of Alpine subterranean Trechini (Coleoptera: Carabidae). BMC Evolutionary Biology 13:248 http://dx.doi.org/10.1186/1471-2148-13-248

28. HOMBURG K, BRANDT P, DREES C, ASSMANN T 2014 Evolutionarily significant units in a flightless ground beetle show different climate niches and high extinction risk due to climate change. J Insect Conserv 18:781-790 http://dx.doi.org/10.1007/s10841-014-9685-x

29. Den BOER P J 1977 Dispersal power and survival. Carabids in a cultivated countryside (with a mathematical appendix by J. Reddingius). Misch Pap Landbouwhogesch Wageningen 14:1-190.

30. LÖVEI G. 2008 Ecology and conservation biology of ground beetles (Coleoptera, Carabidae) in an age of increasing human dominance. Thesis p 145 http://real-d.mtak.hu/121/1/Lovei.pdf.

31. TURIN H, DEN BOER P. J. 1988 Changes in the distribution of carabid beetles in The Netherlands since 1880. II. Isolation of habitats and long-term time trends in the occurrence of carabid species with different powers of dispersal (Coleoptera, Carabidae). Biol Conserv 44(3):179-200 http://dx.doi.org/10.1016/0006-3207(88)90101-2

32. KOTZE D J, O'HARA R B 2003 Species decline - but why? Explanations of carabid beetle Coleoptera, Carabidae) declines in Europe. Oecologia 135:138-148 http://dx.doi.org/10.1007/s00442-002-1174-3

33. BLOIS J L, WILLIAMS J W, FITZPATRICK M C, JACKSON S T, FERRIER S 2013 Space can substitute for time in predicting climate-change effects on biodiversity. PNAS 110(23):9374-9379 http://dx.doi.org/10.1073/pnas.1220228110

34. JANETSCHEK H 1949 Tierische Sukzessionen auf hochalpinem Neuland. Nach Untersuchungen am Hintereis-, Niederjoch- und Gepatschferner. Ber Nat Med Ver Innsbruck 48/49:1-215

35. SCHMÖLZER K 1962 Die Kleintierwelt der Nunatakker als Zeugen einer Eiszeitüberdauerung. Mitt Zool Mus Berlin 38(2):171400

36. KAUFMANN R 2001 Invertebrate succession on an alpine glacier foreland. Ecology 82(8):2261-2278 doi: 10.1890/0012-9658(2001 )082[2261:ISOAAG]2.0.CO

37. BRAMBILLA M, GOBBI M 2013 A century of chasing the ice: delayed colonization of ice-free sites by ground beetles along glacier forelands in the Alps. Ecography 37(1):33-42 http://dx.doi.org/10.1111/j.1600-0587.2013.00263.x

38. GOBBI M, ISAIA M, DE BERNARDI F 2010 Arthropod colonisation of a debris-covered glacier. The Holocene, 21(2):343-349. http://dx.doi.org/10.1177/0959683610374885

39. CASALE A, VIGNA TAGLIANTI A 1993 I Coleotteri Carabidi delle Alpi occidental e centro-occidentali (Coleoptera, Carabidae). Biogeographia Lavori Soc. it Biogeografia 18(1995):391-427

40. RASO D, SINT D, MAYER R, PLANGG S, RECHEIS T, BRUNNER S, KAUFMANN R, TRAUGOTT M 2014 Intraguild predation in pioneer predator communities of alpine glacier forelands. Mol Ecol 23:3744-3754 http://dx.doi.org/10.1111/mec.12649

41. HOMBURG K, SCHULDT A, DREES C. \& ASSMANN T 2013 Broad-scale geographic patterns in body size and hind wing development of western Palaearctic carabid beetles (Coleoptera: Carabidae). Ecography 36:166-177 http://dx.doi.org/10.1111/j.1600-0587.2012.07488.x

42. PIZZOLOTTO R, SAPIA M, ROTONDARO F, SCALERCIO S, BRANDMAYR P 2010 A Georeferenced Biodiversity Databank for Evaluating the Impact of Climate Change in Southern Italy Mountains. In: Christian Körner, Eva M. Spehn eds. - Data mining for global trends in mountain biodiversity, p 137-147. CRC Press, Taylor \& Francis, ISBN 978-1-4200-8369-9.

43. PIZZOLOTTO R, GOBBI M, BRANDMAYR P 2014 Changes in ground beetle assemblages above and below the treeline of the Dolomites after almost thirty years (1980/2009). Ecol Evol 4(8):1284-1294 http://dx.doi.org/10.1002/ece3.927

44. SPARKS T, CRICK H 2015 Biodiversity Climate Change impacts report card technical paper. 12 . The impact of climate change on biological phenology in the UK. http://www.nerc.ac.uk/research/ partnerships/lwec/products/report-cards/biodiversity/papers/ source12/.

45. MATALIN A V 2007 Typology of Life Cycles of Ground Beetles (Coleoptera, Carabidae) in the Western Palaearctic. Entomol Rev 87(8):947-972 http://dx.doi.org/10.1134/S0013873807080027

46. ERWIN T L 1979 Thoughts on the evolutionary history of ground beetles: hypotheses generated from comparative faunal analyses of lowland forest sites in temperate and tropical regions. In: Erwin T L et al. (ed) Carabid Beetles. Their Evolution, Natural History, and Classification. Junk, The Hague p 539-92

47. CULVER D C, SKET B 2000 Hotspots of subterranean biodiversity in caves and wells. J Cave Karst Studies 62:11-17

48. ZAGMAJSTER M, CULVER D C, SKET B 2008 Species richness patterns of obbligate subterranean beetles (Insecta: Coleoptera) in a global biodiversity hotspot - effect of scale and sampling intensity. Diversity Distrib 14:95-105

49. SCHULDT A, ASSMANN T 2011 Belowground carabid beetle diversity in the western Palaearctic - effects of history and climate on range-restricted taxa (Coleoptera, Carabidae). ZooKeys 100 461-474 http://dx.doi.org/10.3897/zookeys.100.1540 
50. VIGNA TAGLIANTI A 2007 Fauna Europaea: Carabidae. In: Audisio P (ed) Fauna Europaea: Coleoptera 2. Fauna Europaea 1.3 www.faunaeur.org.

51. BRANDMAYR P, GIORGI F, CASALE A, COLOMBETTA G, MARIOTTI L, VIGNA TAGLIANTI A, WEBER F, PIZZOLOTTO R 2013 Hypogean Carabid Beetles as Indicators of Global Warming? Environ Res Lett 8, p 11

http://dx.doi.org/10.1088/1748-9326/8/4/044047

Suppl. data: stacks.iop.org/ERL/8/044047/mmedia

52. JONES P D, LISTER D H, OSBORN T J, HARPHAM C, SALMON M, MORICE C P 2012 Hemipheric and land-surface air temperature variations: an extensive revision and an update to 2010. J Geophys Res 117 D05127

53. SCHULDT A, ASSMANN T 2009 Environmental and historical effects on richness and endemism patterns of carabid beetles in the western Palaearctic. Ecography 32:705-714 http://dx.doi.org/10.1111/j.1600-0587.2009.05763.x

54. CULVER D C, PIPAN T 2014 Shallow Subterranean Habitats. Ecology, Evolution, and Conservation. Oxford University Press, NY, U.S.A. p 258 ISBN 978-0-19-964617-3

55. CASALE A, JALŽIĆ B, LOHAJ R, MLEJNEK R 2012 Two new highly specialized subterranean beetles from the Velebit Massif (Croatia): Velebitaphaenops (new genus) giganteus Casale \& Jalzic, new species (Coleoptera: Carabidae: Trechini) and Velebitodromus ozrenlukici Lohaj, Mlejnek \& Jalzic, new species (Coleoptera: Cholevidae: Leptodirini). Nat Croat 21(1):129-153.

56. MATEU J, BELLÉS X 2003 Position systématique et remarques biogéographiques sur Dalyat mirabilis Mateu, 2002 (Coleoptera : Adephaga : Promecognathidae), cavernicole du Sud-Est Ibérique. Ann Soc entomol Fr (n.s.) 39(4):291-303

57. BREGOVIĆ P, ZAGMAJSTER M 2016 Understanding hotspots within a global hotspot - identifying the drivers of regional species richness patterns in terrestrial subterranean habitats. Insect Conservation and Diversity. http://dx.doi.org/10.1111/icad.12164

58. ZAGMAJSTER M, CULVER DC, CHRISTMAN MC, SKET B 2010 Evaluating the sampling bias in pattern of subterranean species richness - combining approaches. Biodiversity and Conservation 19:3035-3048 http://dx.doi.org/10.1007/s10531-010-9873-2

59. SCALERCIO S, BONACCI T, MAZZEI A, PIZZOLOTTO R, BRANDMAYR P 2014 Better up, worst down: bidirectional consequences of three decades of changes on a relict population of Erebia cassioides. J Insect Conserv 18(4):643-650 http://dx.doi.org/10.1007/s10841-014-9669-x

60. DOMÍNGUEZ-VILLAR D, LOJEN S, KRKLEC K, BAKER A, FAIRCHILD I J 2014 Is global warming affecting cave temperatures? Experimental and model data from a paradigmatic case study. Clim Dyn 45:569-581

http://dx.doi.org/10.1007/s00382-014-2226-1 